\title{
Perception of Risk Factors and Determination of Risk Management Strategies According to Agricultural Enterprise Typologies
}

\author{
Zuhal Karakayacı $^{1 *}$, Zeki Bayramoğlu², Orhan Gündüz ${ }^{3}$, Yusuf Çelik ${ }^{4}$ \\ ${ }^{1 *}$ The Department of Agricultural Economics, Agricultural Faculty, Selcuk University 42130 Konya, Turkey \\ Corresponding author, E-mail: zkarakayaci@gmail.com, ORCID: https://orcid.org/0000-0003-2933-5608 \\ ${ }^{2}$ The Department of Agricultural Economics, Agricultural Faculty, Selcuk University 42130 Konya, Turkey \\ E-mail: zbayramoglu@gmail.com,ORCID: https://orcid.org/0000-0003-3258-3848 \\ ${ }^{3}$ Local Government Program, Battalgazi Vocational School, Inonu University, 44280 Malatya, Turkey \\ E-mail: orhangunduz@inonu.edu.tr, ORCID: https://orcid.org/0000-0002-2357-0802 \\ ${ }^{4}$ The Department of Agricultural Economics, Agricultural Faculty, Selcuk University 42130 Konya, Turkey \\ E-mail: yucelik@selcuk.edu.tr
}

\begin{tabular}{|c|c|}
\hline A R T I C L E I N F O & A B S T R A C T \\
\hline $\begin{array}{l}\text { Keywords: } \\
\text { Risk factors } \\
\text { Risk management strategies } \\
\text { Risk behaviours } \\
\text { Enterprise Typology } \\
\text { FADN }\end{array}$ & $\begin{array}{l}\text { In this study, it was aimed to determine the risk management strategies and the level of risk } \\
\text { perception of the entrepreneurs in agricultural enterprises classified according to production } \\
\text { activities. Risk behaviours of entrepreneurs were examined according to the enterprise typologies, } \\
\text { and the reference game was used for this purpose. The success of the economic activities of the } \\
\text { enterprises was determined by an analysis of the annual operating results. The risk perception was } \\
\text { investigated according to the enterprise typology. As a result, it was determined to be perceived } \\
\text { as risk factors: drought, fluctuation of input and product prices in the livestock enterprises; } \\
\text { drought, precipitation, pests, frost and hail in the mixed plant enterprises; drought, precipitation, } \\
\text { frost and hail in the mixed plant and livestock enterprises; pest, diseases, hail, drought and } \\
\text { precipitation in the specialized perennial enterprises; storm, capital shortage, loans, price } \\
\text { fluctuation, yield fluctuation and fire in the specialized horticulture enterprises; drought, frost, } \\
\text { hail, insufficient and unpredictable precipitation in the crop enterprises. The general information } \\
\text { on agricultural issues, the implementation of new farming techniques, the diversity in production, } \\
\text { the planned debt, the contract production, agricultural protection and the market follow were found } \\
\text { out as management strategies for these risk factors. }\end{array}$ \\
\hline
\end{tabular}

(c) (1) (9) This work is licensed under Creative Commons Attribution 4.0 International License

\section{Introduction}

Agricultural enterprises carry out their activities with low profit margins and low capital turnover rate. Therefore, it cannot be take place high saving and accumulation of capital. This situation threatens the sustainability of enterprises in possible income reduction. It is occurred that the agricultural activities are complicated and also difficult, while the effects that exposed agricultural sector are taken into consideration as an economic, social, natural and technical. The economic factors are mostly related to the market mechanism and there is different effect for each product cultivated. Because each agricultural product has its own characteristic and the market structure arises from this characteristic. Social factors are the demographic and cultural characteristics which belong to the farm manager, families and neighborhood of the agricultural enterprises. Technical factors are effects regarding the adoption of technology in agricultural production, the technology use and the adoption of innovation. It is known that the most effective factor on the agricultural production is the natural factors. It can be observed in two groups as climatic factors and disease/insect factors.
The factors determined as risk in terms of agricultural production are also effective on the structure of agricultural enterprises. The agricultural enterprises have different production activities, even though they are in the same region. The factors affecting this are human resources, capital, input procurement, product prices, technology, market structure, environment, ecology, soil structure etc. Differences in the structural characteristics of agricultural enterprises can be determinative on the response level of risk and uncertainties. Moreover, the effects of the risks vary according to the structures of the enterprises, while they can be also perceived at different levels by the managers of enterprises. In this study, the level of risk perception of the enterprises managers and the determination of management strategies were conducted and compared according to enterprise typologies.

The impact revealed by the agricultural policies applied in EU on the enterprises is examined by taking as the basis the different regions, economic growth classes and different enterprise types and in this way, it is studied in which regions, economic growth class and enterprise type 
the applied policies are effective or ineffective. On the other hand; within the scope of production economy studies, resource use efficiency or inefficiency is also examined according to the region, economic growth class or enterprise types. The impact of the risk and uncertainty factors on different enterprise types significantly changes. For this reason; the determination that on which enterprise types the risk and uncertainty factors are more efficient will be efficient in the selection of the rational production activities by the enterprises and in the political decisions to be reached.

The city of Konya determined as the study area takes place in the middle section of Turkey. Total agricultural fields of Konya form $8.25 \%$ of the total fields of Turkey. There are totally 1.886 .156 ha agricultural fields in Konya and $73.69 \%$ of them consists of the planted field area, $22.49 \%$ consists of fallow land, $1.38 \%$ consists of vegetable-planted area and $2.44 \%$ consists of the area in which fruits and spice plants. $78.29 \%$ of the planted agricultural areas consist of grains, $6.26 \%$ consists of oil seeds, $5.03 \%$ consists of forage crops and $3.48 \%$ consists of legumes. The first rank belongs to carrot with 344.093 tons in the vegetable production of Konya. It is followed by table tomato with 120.602 tons. Vegetable production of Konya forms $2.88 \%$ of the vegetable production of Turkey. Konya has $5.39 \%$ of the cattle number of Turkey, $5.62 \%$ of sheep number and $2.26 \%$ of goat number (TSI, 2017).

Agricultural enterprises are the economic units forming the agriculture sector and it is known that there is a social bonding with the administrator or staff of these enterprises. For this reason, the economically hard situations of the agricultural enterprises have brought together the social problems for the enterprise manager and his/her family. Within the scope of this study; risk factors of agricultural enterprise managers have been perceived in agricultural production and strategy development conditions, opportunities and factors affecting this have been examined. Acknowledgement of these elements is important for the entrepreneurs to reach decisions, managers to develop policies and private sector (insurance companies, banks, associations and agricultural industries) to determine strategy.

When the studies previously conducted regarding the determination of the risk factors and risk management strategies have been examined, it has been seen that there is no study taking the specialization levels (typologies/types) of the enterprises into consideration. Dillon and Scandizzo (1978) have compared the risk prevention alternatives of the enterprises processing property and joint land. Martin and McLeay (1998) have collected questionnaire data without any discrimination with 1.384 enterprises in New Zealand and separated them into five groups as those decreasing the income risk, capital managers, part-time workers, debt and market risk managers and production managers. Saner (1998) has conducted risk management by using the data collected from dairy farming enterprises, examined the activity results according to their risk groups and their insurance status and determined the factors affecting the risk. Patrick and Musser (1999) have determined the risk sources affecting the agricultural production in large-scale agricultural enterprises and determined the risk management strategies applied by the farmers against them. Özsayın and Çetin (2004) have studied the risk sources and risk strategies in the dairy farming enterprises. In the study conducted by Hazneci (2009), risk analysis of the agricultural enterprises conducting dairy farming in Amasya city Merzifon district has been conducted. There are many studies conducted in this issue (Patrick et al., 2000; Akçaöz, 2001; Bozoğlu et al., 2001; Vergara et al., 2001; Karahan, 2002; Akçaöz et al., 2006; Şahin et al., 2008).

Moreover; in the conducted literature reviews, no studies have been conducted regarding the determination of the risk factors and strategies according to the enterprise typologies. This study will also contribute to the literature with this aspect.

\section{Material and Method}

The data used in the study have been attained by conducting face-to-face questionnaire with the agricultural enterprises showing activities in the city of Konya which is the study area. The number of enterprises active in Konya has been determined as 107633 according to Farmer Register System. 396 enterprises have been determined as samples according to stratified random sampling method and face-to-face questionnaire has been applied.

The number of the samples to be studied according to the stratified random sampling method has been calculated by using the formula below (Yamane, 1967).

$$
\begin{gathered}
\mathrm{n}=\frac{\sum\left(\mathrm{N}_{\mathrm{h}}-\mathrm{S}_{\mathrm{h}}\right)^{2}}{\mathrm{~N}^{2} \mathrm{D}^{2}+\sum \mathrm{N}_{\mathrm{h}} \mathrm{S}_{\mathrm{h}}^{2}} \\
\mathrm{D}=\mathrm{d}^{2} / \mathrm{z}^{2}
\end{gathered}
$$

n : Sample size

$\mathrm{N}$ : Number of enterprises in the population

$\mathrm{N}_{\mathrm{h}}$ : Number of enterprises in the stratum $\mathrm{h}$

$\mathrm{S}^{2} \mathrm{~h} \quad$ : Variance of the stratum $\mathrm{h}$

d : Permitted margin of error in the population mean

$\mathrm{z} \quad$ : Represents the $\mathrm{z}$ value from the standard normal distribution tablet o the error rate

The formula $\mathrm{N}_{\mathrm{h}} \mathrm{S}_{\mathrm{h}} \times \mathrm{n} / \Sigma \mathrm{N}_{\mathrm{h}} \mathrm{S}_{\mathrm{h}}$ was used to determine the distribution of the defined sample size across the various strata.

The Method Used in the Determination of the Enterprise Typologies

While determining the type of an agricultural enterprise according to EU FADN system, total standard gross profit of the enterprise is taken as the basis. Standard Gross Profit (SGP) is calculated with the subtraction of the product's private changing costs from the gross production value (GPV) of the agricultural activities taking place in the enterprise.

The gross production value of the products produced in the enterprise is calculated by multiplying it with the market sale prices if it is sold in the enterprise without considering the assessment way of the attained product (sale, giving to the worker, family consumption etc.) and if it is sold in the market with the farmyard prices. In addition; the value increases in the vegetative and animal production are also taken into account. Standard gross 
profit of the product has been calculated with the subtraction of the private changing costs made for producing this product from the total production value attained from the products.

While calculating SPG according to FADN system, the private changing costs in the vegetative and animal production to be subtracted from the vegetative and animal production value are given in table 1 below.

The total standard gross profit of the enterprise is determined by the addition of standard gross profits calculated from the products produced in the examined enterprises. According to FADN system, the type of an enterprise is determined by taking into consideration the proportional contribution of the different activities to the total standard gross profit of the enterprise. Therefore; the enterprise is defined as the specialized enterprise related to that activity if the SGP of an activity has a share of $2 / 3$ and above than the total SGP of that enterprise. If the contributions of the activities taking place in the enterprise to SGP are below $2 / 3$, the enterprise is defined as mixed vegetative or animal enterprise.
According to EU FADN system, the enterprise typology defines 9 general and 17 basic enterprise types and also, these 17 types are separated into 50 private types. In this way, the enterprise has been arranged as comprehensive enough in a way that it will cover many different enterprise types. In this study, 9 general enterprise type classifications of the enterprises have been considered. 9 general enterprise types of the enterprises in FADN system have been determined as 1) Specialized field crops cultivation, 2) Specialized horticultural crops cultivation, 3) Permanent plant cultivation (Orcharding), 4) Specialized forage cattle breeding, 5) Specialized cattle breeding feeding with grain (poultry), 6) Mixed plant production enterprises, 7) Mixed livestock enterprise, 8) Mixed plant and animal production enterprises, 9) Unclassified enterprises.

Within the scope of the aforementioned methodology, the types of the agricultural enterprises taken to the sampling in the study area have been detected. In this way, risk management approaches and risk management strategies in different enterprise types have been analysed (Table 1).

Table 1 Specific variable costs in plant and animal production

\begin{tabular}{|c|c|c|}
\hline \multirow{3}{*}{$\begin{array}{c}\text { Specific Variable } \\
\text { Costs }\end{array}$} & & Seed and seedling costs \\
\hline & $\begin{array}{l}\text { Specific Variable Costs in } \\
\text { Plant Production }\end{array}$ & $\begin{array}{l}\text { Fertilizers and soil amendment cost, } \\
\text { Cost of plant protection products, } \\
\text { Other Specific Variable Costs } \\
\text { - } \quad \text { Soil analysis costs, } \\
\text { - } \quad \text { Plastification (eg. for strawberry) } \\
\text { - } \quad \text { Protection and processing costs of products, } \\
\text { - } \quad \text { Costs for storage and preparation of products for the } \\
\text { - } \quad \text { market, } \\
\text { - } \quad \text { Costs for places rented for less than one year for the } \\
\text { - } \quad \text { product sale, } \\
\text { - } \quad \text { packagial marketing costs (such as grading, cleaning, } \\
\text { - } \quad \text { Heating cost, } \\
\text { - } \quad \text { Drying cost, } \\
\text { Specific Variable Costs in Forest Products } \\
\text { - } \quad \text { Plant feeding costs (including those produced in } \\
\text { enterprise), } \\
\text { - } \text { Short-term land costs, } \\
\text { - } \text { Bed preparation costs, } \\
\text { - } \text { Protection and storage costs, } \\
\text { Other costs. }\end{array}$ \\
\hline & $\begin{array}{l}\text { Specific Variable Costs in } \\
\text { Animal Production }\end{array}$ & $\begin{array}{l}\text { Feed purchased } \\
\text { Feed produced in enterprise } \\
\text { Other Specific Variable Costs } \\
\text { Water cost, } \\
\text { Veterinary fees, vaccination and medication costs, } \\
\text { Natural overproduction and artificial insemination costs, } \\
\text { Cost of performance testing, } \\
\text { Expenses of publication and membership fee, } \\
\text { Cleaning costs for equipment, } \\
\text { Costs of product process and special marketing, } \\
\text { Land and building rent costs with short-term for storing animal } \\
\text { products }\end{array}$ \\
\hline
\end{tabular}


Table 2 Proportional distribution of enterprises according to typology and risk groups

\begin{tabular}{ll|rr}
\hline \multicolumn{1}{c}{ Typology Group } & \multicolumn{1}{c}{ Risk Group } & Number of Enterprise \\
\hline \multirow{2}{*}{ (SFC) Specialized Field Cropping } & Risk Averse & 216 & 72.24 \\
& Risk Lover & 83 & 27.76 \\
& Total & 299 & 75.51 \\
& Risk Averse & 7 & 70.00 \\
& Risk Lover & 3 & 30.00 \\
& Total & 10 & 2.53 \\
& Risk Averse & 24 & 63.16 \\
(MCL) Mixed Crops and Livestock & Risk Lover & 14 & 36.84 \\
& Total & 38 & 9.60 \\
\hline \multirow{3}{*}{ (SPC) Specialized Permanent Crops } & Risk Averse & 23 & 67.65 \\
& Risk Lover & 11 & 32.35 \\
& Total & 34 & 8.59 \\
\hline \multirow{3}{*}{ (SH) Specialized Horticulture } & Risk Averse & 7 & 58.33 \\
& Risk Lover & 5 & 41.67 \\
& Total & 12 & 3.03 \\
\hline \multirow{2}{*}{ (MC) Mixed Cropping } & Risk Averse & 2 & 66.67 \\
& Risk Lover & 1 & 33.33 \\
\hline \multirow{2}{*}{ Total } & Total & 3 & 0.76 \\
\hline & Risk Averse & 279 & 70.45 \\
\hline
\end{tabular}

Method Used in the Determination of Risk Factors and Strategies

Risk factors have been examined in four groups as natural, technical, social and economical. By taking the changes in the risk factors and strategies according to the enterprise types into consideration, risk factors and alternative risk management strategies have been determined as a result of the literature review. The perceptions of the enterprise managers in the issue of risk factors and their preferences regarding the risk management strategies have been determined with fivepoint likert scale. Likert scale has been arranged as "strongly agree", "agree", "indecisive", "disagree" and "strongly disagree" (Karagöz and Ekici, 2004) and the preferences of the enterprise managers in the issue of the risk factors and risk management strategies have been tried to be determined. "Likert scale" is commonly used in both the determination of the perception levels of the risk factors (Özsayın and Çetin, 2004, Akçaöz et al., 2006) and in the determination of the preference levels in other areas (Karagöz and Ekici, 2004).

Method Used in the Determination of the Attitudes of the Producers towards Risk

Which group the farmers to whom questionnaire has been given take place in terms of their attitudes towards risk (risk lover, non-reactive to risk and risk-averse) has been determined with the help of reference gamble and preference scale methods. The attitudes of the producers towards risk have been determined via the preferences they have made among hypothetical options. The points in which farmers have remained unresponsive between the risky alternatives and the alternatives whose result is certain show the risk bearing tendencies (risk attitudes) of the people (Holloway, 1979).

Which risk attitude group the producers have taken place has been detected by the following stages (Ceyhan et al., 1997).
- It has been specified that a reward will be given to the producer depending on a certain probability.

- A reward alternative which is smaller, but more guaranteed that the one given at first step has been presented to the producer. Which one does the producer prefer? Of s/he has preferred the first one, the value of the second alternative has been increased. This process has been sustained until the person is indecisive between these two alternatives.

- The probability value in the first step has been increased and the process in the second step has been repeated.

- As a result, their attitude towards risk has been determined by taking the reward and alternative into consideration.

\section{Findings of The Study}

Proportional Distribution of the Examined Enterprises According to Typology and Risk Groups

Questionnaire has been applied with 396 enterprises representing the city of Konya. In this respect; $75.51 \%$ of the enterprises to which questionnaire applied has been called as field crop producers. $2.53 \%$ of other enterprises has been called as mixed livestock, $9.60 \%$ as mixed crops and livestock, $8.59 \%$ of them as specialized permanent crops, $3.03 \%$ of them as specialized horticultural (vegetable and flower) and $0.76 \%$ of them as mixed plant product enterprises. This denotation has been made by taking the gross production value of the enterprises into consideration. According to FADN methodology, the typology of the enterprises is determination by considering the gross production value and the enterprises having a production activity whose gross production value is $50 \%$ and above take the name of that production activity (Table 2). 
Furthermore; $70.45 \%$ of the managers has been determined as risk averse and $29.55 \%$ of them has been determined as risk-lover in the examined enterprises. This situation shows differences according to the enterprise typologies. The highest risk averse enterprise managers $(72.24 \%)$ are from the enterprises conducting specialized field crops cultivation. The zone in which these enterprises are in majority is the $5^{\text {th }}$ Zone, grain cultivation is common in this zone and generally grain fallow alternation is conducted. Region ecology is not convenient for the product variation. Because the enterprises do not have any alternative income resource, the managers not to love the risk in this zone is an expected situation.

The highest risk lover enterprise managers $(41.67 \%)$ are from the enterprises cultivating specialized horticultural products. Within the scope of the study; the vegetable production of the enterprises in this typology is in majority, the vegetable production activity is in an intensive structure and it is more sensible to climatic phenomena, illnesses and pests. Moreover; the organic structure of the vegetable is not convenient for the open storage conditions. This situation also includes the market (price) risk.

Economic Performance of Enterprises According to Enterprise Typologies and Risk Attitudes

One of the most important criteria revealing the result of one-year economical activities in agricultural enterprises and used in the comparison of these results to the results of other agricultural enterprises is pure product; because, the pure product calculation is conducted by bringing the enterprises on the same basis with the assumption that they do not hold any debtless and rentpartner field. Therefore; this criterion has an importance in the comparison of the enterprises with one another. Pure product is calculating with the subtraction of the enterprise costs from the gross product value of the enterprise.

The net income per enterprise in general of all the enterprises changes between $6300 \$-68300 \$$ depending on the enterprise types and this value is $18600 \$$ as the average of all the enterprises. While the net income per enterprise is $15124 \$$ in the risk averse enterprises in the average of the enterprises, this is $20015 \$$ in the risk lover enterprises. The net income per decare in the average of the enterprises changes between 52.90\$-256.10\$ depending on the enterprise types and this value is $127.40 \$$ on average (Table 3). It has been determined that in all the enterprises, the highest net income per decare has been attained from the specialized horticulture (vegetable and flower) enterprise type.

In the agricultural enterprises, agricultural income criterion is calculated for the purpose of determining the income attained in return for the business administration, equity capital and family labour force. Agricultural income is calculating by subtracting the debt interests and rents from the pure product value and adding the family labour force fee.

The agricultural income per enterprise in general changes between $4400 \$-6600 \$$ depending on the enterprise types and this value is $6200 \$$ as the average of all enterprises. While agricultural income per enterprise in the risk averse enterprises on average is $5656 \$$, it is $6437 \$$ in risk lover enterprises. The agricultural income per decare changes between 32.20\$-133.10\$ on average depending on the enterprise types and this value is $42.60 \$$ on average for all the enterprises. It has been determined that in all the enterprises, the highest agricultural income per decare has been attained from the enterprise type of specialized permanent plant cultivation.

Risk Factors and Risk Management Strategies According to Enterprise Typologies

The production activities carried out by the agricultural enterprises contain high risk and uncertainty as per their nature. Risk and uncertainties show differences depending on the production activity. Agricultural enterprises have been classified according to their production activities by taking FADN system into consideration and their typologies have been determined. Risk resources and risk strategies have been determined for each enterprise typology. The city of Konya has a wide area and it contains different ecologies inside itself. The risks and uncertainties subjected by the production activities are also different depending on the different ecological structures. 43 risk resources have been determined for the production activity conducted by the agricultural enterprises showing activities in the study area (Table 4).

When the received responses have been examined, it has been observed that the highest-perceived risk resources are respectively drought, irregular precipitation, insufficient precipitation, frost and hail. Especially the expression of the risk related to drought and precipitation by the producers is an expected and possible situation.

Table 3 Economic performance of the enterprises according to typology

\begin{tabular}{|c|c|c|c|c|c|c|c|c|c|}
\hline \multirow{3}{*}{$\begin{array}{c}\text { Typology } \\
\text { Group }\end{array}$} & \multicolumn{4}{|c|}{ Net Income } & \multicolumn{5}{|c|}{ Agricultural Income } \\
\hline & \multirow{2}{*}{$\begin{array}{c}\text { Gross } \\
\text { Income } \\
1000 \$\end{array}$} & \multirow{2}{*}{$\begin{array}{l}\text { Operatin } \\
\text { g Costs } \\
1000 \$\end{array}$} & \multicolumn{2}{|c|}{ Net Income } & \multirow{2}{*}{$\begin{array}{c}\text { Debt } \\
\text { Interest \$ }\end{array}$} & \multirow[b]{2}{*}{ Rents \$ } & \multirow{2}{*}{$\begin{array}{c}\text { Family } \\
\text { Labor Fee } \\
1000 \$\end{array}$} & \multicolumn{2}{|c|}{ Agricultural Income } \\
\hline & & & $1000 \$$ & $\$ / \mathrm{da}$ & & & & $1000 \$$ & $\$ / \mathrm{da}$ \\
\hline SFC & 39.20 & 20.40 & 18.80 & 113.70 & 1221.80 & 987.00 & 5.20 & 6.40 & 38.80 \\
\hline ML & 35.60 & 22.00 & 13.60 & 256.10 & 811.50 & 107.30 & 4.10 & 4.90 & 92.90 \\
\hline MCL & 36.00 & 22.30 & 13.70 & 128.40 & 1126.50 & 949.80 & 5.40 & 6.60 & 61.50 \\
\hline SPC & 17.40 & 9.00 & 8.40 & 254.40 & 230.30 & 8.10 & 4.20 & 4.40 & 133.10 \\
\hline $\mathrm{SH}$ & 129.60 & 61.30 & 68.30 & 374.10 & 877.70 & 3483.10 & 5.00 & 5.90 & 32.20 \\
\hline $\mathrm{MC}$ & 18.00 & 11.70 & 6.30 & 52.90 & 362.70 & 306.50 & 5.00 & 5.40 & 45.40 \\
\hline Average & 39.30 & 20.70 & 18.60 & 127.40 & 1101.40 & 941.50 & 4.80 & 6.20 & 42.60 \\
\hline
\end{tabular}

At the date of study $1 \$=2.61$ Turkish Liras. 
Table 4 Perspective of Enterprises on Agricultural Risk Sources

\begin{tabular}{l|ccll|c}
\multicolumn{1}{c|}{ Risk Factors } & Mean & $\begin{array}{l}\text { Std. } \\
\text { Dv. }\end{array}$ & Risk Factors & Mean & $\begin{array}{c}\text { Std. } \\
\text { Dv. }\end{array}$ \\
\hline Drought & 4.52 & 0.90 & Disease/death in the family & 3.17 & 1.25 \\
Irregular precipitation & 4.27 & 0.95 & Family relationships & 3.07 & 1.26 \\
Insufficient precipitation & 4.34 & 0.86 & Lack of family labour & 3.12 & 1.25 \\
Extreme precipitation & 3.75 & 1.31 & Changes in the family of farmer & 2.95 & 1.27 \\
Wind/storm & 3.70 & 1.19 & Theft & 3.01 & 1.52 \\
Frost & 4.11 & 1.00 & Labour accidents & 3.30 & 1.40 \\
Hail & 4.12 & 0.95 & Fire & 3.32 & 1.38 \\
Pests (sunn) & 3.88 & 1.08 & Distance to selling area & 3.05 \\
Plant diseases & 3.81 & 0.93 & Difficulty in providing input & 1.43 \\
Epidemic Animal Diseases & 2.93 & 1.37 & Area of capacity for cowshed/ poultry & 3.27 & 1.32 \\
& & house/sheepfold & 2.55 & 1.38 \\
Non-epidemic Diseases & 2.58 & 1.31 & Land inadequacy or excess & 3.26 & 1.27 \\
Death of animals & 2.86 & 1.38 & Distribution of work & 3.05 \\
Fluctuation in product prices & 3.84 & 1.02 & Technological development and change & 1.30 \\
Variability in input prices & 3.91 & 0.99 & Changes in product yield & 3.50 & 1.22 \\
Changes in interest rate & 3.49 & 1.21 & Artificial insemination & 3.58 & 1.25 \\
Sufficient or insufficient capital & 3.66 & 1.07 & Conjuncture fluctuations & 2.57 & 1.38 \\
Be able to find finance & 3.38 & 1.27 & Length of the marketing chain & 2.66 & 1.24 \\
Enterprise debts & 3.67 & 1.18 & Non-keeping accounting records & 2.53 & 1.36 \\
Non-enterprise debts & 3.34 & 1.36 & Divided into shares of land & 2.48 & 1.43 \\
Change of government policy & 3.61 & 1.27 & Extension organization & 2.90 & 1.34 \\
Lack of support and incentive & 3.70 & 1.18 & Imperfect marketing & 2.88 & 1.29 \\
Difficulty to find labour & 2.97 & 1.38 & & 3.01 & 1.35 \\
\hline
\end{tabular}

Table 5 Perspective of Enterprises on Risk Management Strategies

\begin{tabular}{l|ccllcc}
\hline \multicolumn{1}{c|}{ Strategies } & Mean & $\begin{array}{l}\text { Std. } \\
\text { Dv. }\end{array}$ & Strategies & Mean & $\begin{array}{c}\text { Std. } \\
\text { Dv. }\end{array}$ \\
\hline Following of input marketing & 3.61 & 1.34 & Agricultural contention & 3.96 & 0.90 \\
Crop insurance & 2.62 & 1.41 & Acquaint with output market & 3.89 & 0.91 \\
Insurance of family and worker & 2.81 & 1.43 & Activity diversity & 3.63 & 1.19 \\
Organization & 3.29 & 1.43 & Keeping accounting records & 2.41 & 1.45 \\
Diversification of production & 3.67 & 1.19 & Getting agricultural consultancy service & 3.22 & 1.35 \\
activities & 3.21 & 1.45 & Training on agricultural issues & 3.46 & 1.22 \\
Non-agricultural income & 3.66 & 1.29 & Financial futures (if available) & 2.85 & 1.36 \\
Reducing borrowing rate & 3.59 & 1.33 & To benefit from government support & 3.29 & 1.25 \\
Avoiding high interest & 4.00 & 0.99 & Renting idle resources & 2.46 & 1.35 \\
Application of new agricultural & & & & 2.72 & 1.41 \\
techniques & 3.24 & 1.56 & Asset sales & 3.29 & 1.14 \\
Contract farming & 2.77 & 1.49 & Control of non-agricultural consumption & 3.44 & 1.15 \\
Non-enterprises investment & 3.11 & 1.46 & Use of input based on technical knowledge & & \\
Extend product sales for periods & & & &
\end{tabular}

Responses taken from the producers for 24 risk management strategies developed for the purpose of revealing what kind of a method the producers use or how a method could be efficient in the termination of the risk to cope with the faced risks have been analysed and the definitive statistics related to this are given below (Table 5).

The most widely used or usable risk management strategy for Konya plain agricultural enterprises is to give opportunities for the usage of new technologies in agriculture. It is understood from this expression that the technologies which could struggle with especially drought and which will not excessively negatively affect the wealth level of the producer in the insufficiency of precipitation should be used. As well as the renovation in the usage of technology, it has also been specified by the producers that healthy enlightenment about the agricultural control and product market is also one of the most important mechanisms that could be used for the purpose of coping with the risks.

Because the main purpose of the study is to determine the risk resources and risk management strategies according to the enterprise typologies, the aforementioned data have presented short information about the general condition of the local enterprises.

As specified before; enterprises have been classified into 6 different typologies and analysed. The risk resources faced by these enterprises whose typologies are different and the risk management strategies applied by them to cope with these risks are also expected to be different. The risk resources and risk management strategies of the enterprises have been tried to be analysed below depending on different typologies within the direction of the responses taken from the producers. 
Risk Perceptions and Risk Management Strategies of Livestock Enterprises

Risk perceptions of 10 stock breeding enterprises determined as a result of the typological classification conducted according to FADN have been analysed and the results are given in Table 6 . As a result of the analysis, definitive statistics belonging to the highest perceived risk resources have been interpreted.

The most important risk resources for the livestock enterprises showing activities in the city of Konya have been determined as drought, the changes in input prices and fluctuations in the product prices. The test results calculated for the reliability of the responses taken from the producers are very high and these results have revealed that the responses taken from the producers are reliable.
Illnesses and animal deaths are the expected risk factors for the stock breeding enterprises. However; the recent developments in the issue of animal wealth, health and treatment of illnesses have caused the illnesses to be perceived as a low risk factor.

It has been determined that the responses given by the stock breeding enterprises for the most convenient risk management strategies are reliable. These kinds of enterprise managers have specified that the risks related to the activity could be controlled within the light of the information to be attained from the tools such as course, seminar etc. regarding vocational education (Table 7). However; input and product markets are active and market information is needed for supply and marketing.

Table 6 Perceptions of livestock enterprises about risk sources

\begin{tabular}{l|cccc}
\hline Risk Factor & Minimum & Maximum & Mean & Std. Dev. \\
\hline Drought & 4.00 & 5.00 & 4.60 & 0.52 \\
Variability in input prices & 3.00 & 5.00 & 3.85 & 1.04 \\
Fluctuation in product prices & 3.00 & 5.00 & 3.87 & 0.87 \\
\hline
\end{tabular}

Reliability coefficient (alfa): 0.89

Table 7 Best risk management strategies for livestock enterprises

\begin{tabular}{c|cccc}
\hline Risk Strategy & Minimum & Maximum & Mean & Std. Dev. \\
\hline Training seminars. courses about agricultural issues & 4.00 & 4.00 & 4.00 & 0.00 \\
\hline
\end{tabular}

Reliability coefficient (alfa): 0.76

Table 8 Perceptions of mixed crop enterprises about risk sources

\begin{tabular}{l|cccc}
\hline \multicolumn{1}{c|}{ Risk Factor } & Minimum & Maximum & Mean & Std. Dev. \\
\hline Drought & 5.00 & 5.00 & 5.00 & 0.00 \\
Irregular precipitation & 4.00 & 5.00 & 4.67 & 0.58 \\
Insufficient precipitation & 4.00 & 5.00 & 4.67 & 0.58 \\
Pests & 4.00 & 5.00 & 4.33 & 0.58 \\
Frost & 4.00 & 4.00 & 4.00 & 0.00 \\
Hail & 4.00 & 4.00 & 4.00 & 0.00 \\
\hline
\end{tabular}

Reliability coefficient (alfa): 0.83

Table 9 Best risk management strategies for mixed crop enterprises

\begin{tabular}{l|cccc}
\hline \multicolumn{1}{c|}{ Risk strategy } & Minimum & Maximum & Mean & Std. Dev. \\
\hline Reducing borrowing rate & 5.00 & 5.00 & 5.00 & 1.16 \\
Avoiding high interest & 5.00 & 5.00 & 5.00 & 1.43 \\
Application of new agricultural techniques & 4.00 & 5.00 & 4.67 & 0.85 \\
Contract farming & 4.00 & 5.00 & 4.33 & 0.00 \\
Diversification of production activities & 4.00 & 5.00 & 4.33 & 0.95 \\
Agricultural contention & 4.00 & 5.00 & 4.33 & 1.32 \\
Acquaint with output market & 4.00 & 4.00 & 4.00 & 1.29 \\
Activity diversity (crop-livestock) & 4.00 & 4.00 & 4.00 & 1.25 \\
Training seminars. courses about agricultural issues & 4.00 & 4.00 & 4.00 & 1.43 \\
\hline
\end{tabular}

Reliability coefficient (alfa): 0.80

Risk Perceptions and Risk Management Strategies of the Enterprises Conducting More Than One Plant Production (Mixed)

The reliability coefficient of the responses taken for the highest risk resource perceived by 3 enterprises conducting mixed crop production has been found very low at first stage (0.43). At this stage, some of the variables decreasing the reliability such as insufficiency of supports and incentives, work accidents, fire, insufficiency or excessiveness of the enterprise field and not keeping the accounting registers have been extracted from the reliability test and have not been analysed. At this situation, the reliability test regarding the remaining variables has increased very much (0.83).

The most important ones of the factors perceived by the enterprises as a cause to risk have been respectively determined as drought, irregular precipitation, insufficient precipitation, pests, frost and hail (Table 8).

The most important strategy for coping with the faced risks for the mixed vegetative production enterprises have been determined as decreasing the debts and avoiding from loan on interest. However; controlled loan will not threaten the sustainability of the enterprise when faced with risk. Diversity in production is also one of the most commonly known risk management strategies (Table 9). 
Risk Perceptions and Risk Management Strategies of the Mixed Plant and Livestock Enterprises

Although it is known that the agricultural enterprises in Turkey are mostly in mixed structure, approximately $10 \%$ of the agricultural enterprises have entered in the mixed enterprise class in the study area according to the typological classification applied in this study.

The risk resources perceived at highest level by these types of enterprises have been determined as drought, insufficient precipitation, frost and hail (Table 10). The responses taken from the producers have resulted as very reliable.

The struggles to cope with the faced risks for the mixed enterprises are the use of new agricultural techniques, knowledge about the input market, diversification of the activities and the development of the vocational education with the activities such as course and seminar (Table 11). Actually; although the expected situation has been the featuring of the strategies deceasing the impacts of the drought risk, producers have not given the responses revealing this situation.

Risk Perceptions and Risk Management Strategies of the Permanent Plant Enterprises

$8.5 \%$ of the enterprises in the study area are in the typology of long-lived plant cultivation. The factors faced by the enterprises cultivating long-lived plants or seen by them as risky at highest level are respectively pests, hail, drought, irregular and insufficient precipitation and plant disease (Table 12). These responses are important in that they meet the expected factors. The fact that the responses taken from the producers are very reliable has also been separately tested.

While the most important strategy to be used for coping with the risks faced by the enterprises cultivating long- lived plants has been expected as struggle or insurance, it has been expressed by the producers that these risks will be handled better with the use of new technologies as the most important strategy (Table 13).

Risk Perceptions and Risk Management Strategies of the Specialized Horticulture Enterprises

The ratio of the enterprises in the specialized horticulture class is only $2.7 \%$. It has been determined in terms of these types of enterprises that many risk factors are perceived as dangerous at the same level (Table 14). The responses given by the producers to these factors are very reliable.

The most important strategies to be used for coping with the risks faced for the specialized horticulture enterprises have been specified as the use of new technologies and agricultural control (Table 15).

Risk Perceptions and Risk Management Strategies of the Field Crops Enterprises

The city of Konya being the study area is referred as the granary of Turkey. The majority of the enterprises conducting agricultural activities in the city of Konya generally cultivate field products and specifically grain products. $76 \%$ of the enterprises in the study area are in the typology of field crops.

These types of enterprises have shown drought, insufficient and irregular precipitation, frost and hail as the resources at highest risk (Table 16). These results have met the expectations for the field crops.

The most important strategies to be used for coping with the risks faced for the field crops enterprises have been specified as the use of new technologies, agricultural control and knowledge about the product market (Table 17).

Table 10 Perceptions of mixed enterprises about risk sources

\begin{tabular}{l|cccc}
\multicolumn{1}{c|}{ Risk Factor } & Minimum & Maximum & Mean & Std. Dev. \\
\hline Drought & 1.00 & 5.00 & 4.47 & 1.13 \\
Insufficient precipitation & 1.00 & 5.00 & 4.24 & 0.83 \\
Frost & 1.00 & 5.00 & 4.03 & 1.05 \\
Hail & 1.00 & 5.00 & 4.00 & 0.99 \\
\hline
\end{tabular}

Reliability coefficient (alfa): 0.91

Table 11 Best risk management strategies for mixed enterprises

\begin{tabular}{l|cccc}
\hline \multicolumn{1}{c|}{ Risk strategy } & Minimum & Maximum & Mean & Std. Dev. \\
\hline Agricultural contention & 1.00 & 5.00 & 3.97 & 0.91 \\
Application of new agricultural techniques & 1.00 & 5.00 & 3.82 & 1.18 \\
Acquaint with output market & 1.00 & 5.00 & 3.78 & 0.79 \\
Activity diversity (crop-livestock) & 1.00 & 5.00 & 3.55 & 1.16 \\
Following of input marketing & 1.00 & 5.00 & 3.53 & 1.33 \\
Training seminars. courses about agricultural issues & 1.00 & 5.00 & 3.53 & 1.20 \\
\hline
\end{tabular}

Reliability coefficient (alfa): 0.78

Table 12 Perceptions of permanent crops enterprises about risk sources

\begin{tabular}{l|cccc}
\hline \multicolumn{1}{c|}{ Risk Factor } & Minimum & Maximum & Mean & Std. Dev. \\
\hline Crop pests & 1.00 & 5.00 & 4.32 & 1.09 \\
Hail & 2.00 & 5.00 & 4.24 & 0.74 \\
Drought & 1.00 & 5.00 & 4.21 & 0.84 \\
Irregular precipitation & 1.00 & 5.00 & 4.09 & 0.93 \\
Insufficient precipitation & 1.00 & 5.00 & 4.09 & 0.83 \\
Plant diseases & 2.00 & 5.00 & 4.09 & 0.67 \\
\hline
\end{tabular}

Reliability coefficient (alfa): 0.85 
Table 13. Best Risk Management Strategies for Permanent Crops Enterprises

\begin{tabular}{c|cccc}
\hline Risk strategy & Minimum & Maximum & Mean & Std. Dev. \\
\hline Application of new agricultural techniques & 4.00 & 5.00 & 4.44 & 0.50 \\
\hline Reliability coefficient (alfa): 0.84
\end{tabular}

Table 14 Perceptions of Specialized Horticulture Enterprises about Risk Sources

\begin{tabular}{l|cccc}
\hline \multicolumn{1}{c|}{ Risk Factor } & Minimum & Maximum & Mean & Std. Dev. \\
\hline Hail & 4.00 & 5.00 & 4.73 & 0.47 \\
Frost & 4.00 & 5.00 & 4.73 & 0.47 \\
Wind/storm & 4.00 & 5.00 & 4.64 & 0.50 \\
Plant diseases & 3.00 & 5.00 & 4.64 & 0.67 \\
Fluctuation in product prices & 3.00 & 5.00 & 4.55 & 0.69 \\
Variability in input prices & 2.00 & 5.00 & 4.55 & 0.93 \\
Extreme precipitation & 1.00 & 5.00 & 4.18 & 1.17 \\
Insufficient capital & 2.00 & 5.00 & 4.18 & 1.08 \\
Fire & 1.00 & 5.00 & 4.18 & 1.33 \\
Irregular precipitation & 1.00 & 5.00 & 4.09 & 1.38 \\
Enterprise debts & 2.00 & 5.00 & 4.09 & 0.94 \\
Land inadequacy & 2.00 & 5.00 & 4.09 & 1.04 \\
Changes in product yield & 2.00 & 5.00 & 4.09 & 1.14 \\
Drought & 1.00 & 5.00 & 4.00 & 1.41 \\
Insufficient precipitation & 1.00 & 5.00 & 4.00 & 1.34 \\
\hline
\end{tabular}

Reliability coefficient (alfa): 0.93

Table 15 Best risk management strategies for specialist horticulture enterprises

\begin{tabular}{l|cccc}
\hline \multicolumn{1}{c|}{ Risk strategy } & Minimum & Maximum & Mean & Std. Dev. \\
\hline Application of new agricultural techniques & 3.00 & 5.00 & 4.27 & 0.79 \\
Agricultural contention & 2.00 & 5.00 & 4.09 & 1.04 \\
\hline
\end{tabular}

Reliability coefficient (alfa): 0.90

Table 16. Perceptions of field cropping enterprises about risk sources

\begin{tabular}{l|cccc}
\hline Risk Factor & Minimum & Maximum & Mean & Std. Dev. \\
\hline Drought & 1.00 & 5.00 & 4.57 & 0.85 \\
Irregular precipitation & 1.00 & 5.00 & 4.39 & 0.86 \\
Insufficient precipitation & 1.00 & 5.00 & 4.33 & 0.93 \\
Frost & 1.00 & 5.00 & 4.13 & 0.99 \\
Hail & 1.00 & 5.00 & 4.11 & 0.97 \\
\hline
\end{tabular}

Reliability coefficient (alfa): 0.93

Table 17 Best Risk Management Strategies for Field Cropping Enterprises

\begin{tabular}{l|cccc}
\hline \multicolumn{1}{c|}{ Risk strategy } & Minimum & Maximum & Mean & Std. Dev. \\
\hline Application of new agricultural techniques & 1.00 & 5.00 & 3.97 & 0.99 \\
Agricultural contention & 1.00 & 5.00 & 3.97 & 0.92 \\
Acquaint with output market & 1.00 & 5.00 & 3.91 & 0.93 \\
\hline
\end{tabular}

Reliability coefficient (alfa): 0.83

\section{Result and Discussion}

There are many definitive factors on the success of the agricultural production. The most widely known of them is ecological factors. However; the ecological factors are also efficient on the structure of the agricultural enterprises as well as the success of the agricultural production. Ecological factors cover the soil content and climatic properties of the zone in which production is performed. These properties it has are also determinative on the production pattern of the enterprises and it is also efficient on their structure. Ecological structure is dependent on the geographic properties and ecological structure changes as these properties change. The change of ecological structure causes to the differentiation of the production activities and differences in the enterprise structures. Together with the change in the enterprise structures, the faced risk factors also get different. It is important that risk factors should be determined according to the structures of the enterprises and the negative impacts of these risks on the agricultural production should be decreased by conducting risk analysis. The main purposes of this study are the determination of the enterprise structures occurring depending on the changes in the ecological structure and developing risk management strategy by detecting the faced risk factors.

Agricultural production activities structurally show difference and the risk factors and risk management strategies they face are also different. Within the scope of this study; the enterprises bearing the characteristics of the 
production activities have been determined with FADN methodology and named typologically. Enterprises conducting mixed livestock production perceive the market risk and drought as the risk factors due to the changes in the input and product prices. However; the most important inputs of the animal production are attained as a result of vegetative production activity and drought negatively affect all agricultural production activities. Furthermore; while the fluctuation occurring in the animal product prices in the last 5 years have caused to the changes in long-term plans of the livestock enterprises, it has also caused to deviations in the short and medium term plans. Moreover; the increase in the input prices depending on the imported raw materials decreases the profit margin and negatively affects the flexibility of the planning. Regarding these risk factors, the producers have accepted the increase in the knowledge level in agricultural issues as the risk management strategy. However; the enterprise managers having knowledge about the input and product markets will be able to increase the efficiency of the planning by taking the market risk into consideration in their production decisions.

The enterprises conducting mixed crop production have determined the drought, irregular and insufficient precipitation, pests, frost and hail as the risk factors. They have suggested planned loan, use of new agricultural techniques, contracted cultivation, agricultural control and increase in general knowledge level as the management strategy of these risk factors.

In the enterprises conducting mixed plant and animal production; drought, insufficient precipitation, frost and hail have been perceived as risk factor and agricultural control, use of new agricultural techniques and increase in the general knowledge level have been called as risk management strategies.

In the enterprises cultivating permanent plants; pests, hail, drought, irregular and insufficient precipitation and plant illnesses are perceived as risk factors and the application of new agricultural techniques has been expressed as the risk management strategy. The permanent plants commonly cultivated in the city of Konya such as cherry, sour cherry, apple and grape etc. are delicate to the climatic factors and illnesses/pests. However; these risk factors have an important impact on the amount and quality of the product. Also; the altitude of Konya is high and products get frequently frostbitten. This situation negatively affects the income of the producer and sustainability of the enterprise.

The risk factor perceived in the enterprises cultivating specialized horticulture products is high. However; vegetable cultivation is conducted as horticultural product in Konya. Illnesses, pests and climatic factors have a significant impact on the product quality and especially on table vegetable products. Moreover; input costs are high and price fluctuations form a significant risk due to the fact that it has an intensive production. The supply elasticity is lower when compared to other products because the organic structure of the vegetable products is not convenient for storage conditions and the changes in demand form an important income risk. The applications of new agricultural techniques and agricultural controls have been determined as the most important risk management strategies for these risk factors.
Risk factor has been determined as drought, insufficient and irregular precipitation, hail and frost for the enterprises cultivating field crops. Risk management strategies against them have been specified as the application of new agricultural techniques and having knowledge about the product markets.

\section{Acknowledgements}

The data for this study were obtained from the project under the name of "Perception of Risk Factors and Determination of Risk Management Strategies According to Typology of Agricultural Enterprises" supported by The Scientific and Technological Research Council of Turkey [113K429].

\section{References}

Anonymous 2010. Farm accounting data network an a to $\mathrm{z}$ of methodology. http://ec.europa.eu/agriculture/rica/pdf/site _en.pdf, Date of Access: 15.05.2012.

Akçaöz H, Özkan B, Karadeniz CF, Fert C. 2006. Risk sources and risk strategies in agricultural production: a case of study in Antalya Province. Akdeniz University Journal of Agricultural Faculty, 19 (1): 89-97. (In Turkish).

Akçaöz H. 2001. Risk in agricultural production, risk analysis and risk behaviors in Cukurova Region. ( $\mathrm{PhD}$ Thesis), Çukurova University, Institute of Science and Technology, Adana. (In Turkish).

Bozoğlu M, Ceyhan V, Cinemre HA. 2001. The economic structure and the risks of dairy businesses in Tonya district: risk measurement and suitable risk management strategies. Turkey Union of Chambers of Agriculture Publications No: 228. (In Turkish).

Çelik Y. 2012. Methodology for calculating standard operating results by FADN System. 10th Agricultural Economics Congress, 5-7 September, Konya. (In Turkish).

Ceyhan V, Cinemre HA, Demiryürek K. 1997. The determination of risk behavior of farmers in Terme, Samsun, Ondokuz Mayis University, Agricultural Faculty Research Series No:3, Samsun. (In Turkish).

Dillon LJ, Scandizzo PL. 1978. Risk attitudes of subsistence farmers in Northeast Brazil. A Sampling Approach, American Journal of Agricultural Economics, 60 (3):425435 .

Hazneci E. 2009. Risk analysis in dairy cattle farming establishments in Amasya ili Merzifon province. (Master Thesis), Ondokuzmayis University, Graduate School of Natural and Applied Sciences, Department of Agricultural Economics, Samsun. (In Turkish).

Holloway C. 1979. Decision making under uncertainty: models and choices. Prentice-Hall, Inc., Englewood Cliffs, New Jersey.

Karagöz Y, Ekici S. 2004. Statistical techniques and scales used in applied research in social sciences, Cumhuriyet University, Faculty of Economics and Administrative Sciences Journal, 5(1). (In Turkish).

Karahan Ö. 2002. A research on the behavior of agricultural farmers against risk, an example from the Aegean Region. (PhD Thesis), Ege University, Graduate School of Natural and Applied Sciences, Department of Agricultural Economics, İzmir. (In Turkish).

Martin S, McLeay F. 1998. The diversity of farmers' risk management strategies in a deregulated New Zealand environment, Journal of Agricultural Economics, 49 (2): 218233. 
Özsayın D, Çetin B. 2004. Risk and risk management perceptions in animal insured enterprises, Turkey VI. Agricultural Economics Congress, 16-18 October 2004, Tokat, pp: 197 200. (In Turkish).

Saner G. 1998. An experiment on measuring risks in agriculture: dairy cattle sample. Research Project, ISBN.975-96867-0-8. Bornova, İzmir. (In Turkish).

Şahin A, Cankurt M, Günden C, Miran B. 2008. Risk behavior of farmers: a structural equation model application, Dokuz Eylül University Journal of Faculty of Economics and Administrative Sciences, 23 (2):153-172. (In Turkish).

Patrick GF, Musser WN 1999. Large scale farmers' views of sources and responses to risk, Purdue Agricultural Economics Report, September, pp. 8-11.
Patrick GF, Baquet AE, Coble KH, Knight TO. 2000. Hog risk management survey: summary and preliminary analysis, Purdue University, Staff Paper, 00-9, pp:18.

TSI. 2017. Agricultural Production Statistics. www.tüik.gov.tr,

Vergara O, Patrick GF, Knight TO, Baquet AE 2001. Understanding limited resource farmer's risk management decision making: summary and preliminary analysis, A Report From The Understanding Farmer Risk Management Decision Making \& Educational Needs Research Proj. Information Rep. 2001-003, M. S. University, Department of Agricultural Economics, pp: 26.

Yamane T. 1967. Elementary sampling theory. Prentice-Hall Inc.Englewood Cliffs, New Jersey. 